\title{
VERBAL FLUENCY IN CHILDREN WITH INTELLECTUAL DISABILITY: INFLUENCE OF BASIC EXECUTIVE COMPONENTS ${ }^{1}$
}

\author{
Milica GLIGOROVIĆ ${ }^{2}$ Nataša BUHA \\ University of Belgrade \\ Faculty of Special Education and Rehabilitation
}

Phonemic and semantic fluency tasks are frequently used to differentiate executive control roles and the integrity of lexical-semantic representation. The main goal of this study is to determine the influence of basic executive components on phonemic and semantic productivity in children with mild intellectual disability.

The sample consisted of 95 children with unspecified mild intellectual disability (MID), ages 10-13.11. Phonemic fluency was assessed by the Controlled Oral Word Association Test (COWAT), while semantic fluency was assessed by the Category Naming Test (CNT). Cognitive flexibility was assessed by Wisconsin Card Sorting Test (WCST) and Trail Making Test (TMT). Number Manipulation Task (NMT) was used for the verbal working memory assessment, while Day/Night Stroop Task was used for the assessment of inhibitory control.

The results analysis showed that all of the assessed EF components significantly affect phonemic productivity. Semantic productivity significantly depends on WCST and TMT performance. Verbal working memory and inhibitory control do not significantly contribute to semantic productivity.

The results of our study indicate that the discrepancy between phonemic and semantic productivity in children with MID could be directly associated with the basic executive functions components.

Key words: verbal fluency, executive functions, mild intellectual disability

1 Rad je proistekao iz projekta "Kreiranje protokola za procenu edukativnih potencijala dece sa smetnjama u razvoju kao kriterijuma za izradu individualnih obrazovnih programa“, broj 179025 (2011-2014), čiju realizaciju finansira Ministarstvo prosvete, nauke i tehnološkog razvoja Republike Srbije

2 E-mail: gligorovic@fasper.bg.ac.rs 


\section{INTRODUCTION}

Verbal fluency tasks, which can at the same time provide useful information on developmental strategies and lexical-semantic network in childhood, are frequently used for the assessment of planning and application of verbal strategies. Verbal fluency is the ability to generate words according to a given criterion for a limited time period. In phonemic fluency tasks, the participants are expected to produce as many words as possible starting with a given letter, and in semantic fluency tasks as many members of a specific semantic category as possible (such as "fruit" or "supermarket, for example) (Strauss, Sherman, \& Spreen, 2006; Troyer, 2000).

It is considered that phonemic fluency is more dependent on the prefrontal region activity than semantic or categorical fluency tasks. Word retrieval based on the semantic category is a routine strategy of connecting lexical items into a coherent system. In verbal production, a word is primarily selected on the semantic, and subsequently on the phonemic level (Levelt, 1999); therefore semantic fluency tasks performance primarily depends upon largely automated, linguistic representation. Phonemic fluency requires diverse, less conventional approach, which implies more significant activation of executive control and generating non-routine retrieval strategies (Strauss et al., 2006). Grouping and shifting strategies are the indicators of the executive functions (EFs) development, and are therefore considered to be recommendable for the basic cognitive processes assessment in childhood (Filipetti \& Allegri, 2011).

The ability to plan and implement strategies arise when a child reaches approximately 4 years of age, while more significant improvements occur between the ages of 7 and 9 and between 11 and 13 years of age. The final maturity occurs during the adolescent period (Espy, Kaufman, Glisky, \& McDiarmid, 2001; Welsh, 2001). Abilities of effective mental lexicon retrieval on verbal, and generating unique drawings on nonverbal fluency tasks, also demonstrate similar developmental trend with a significant improvement in the period between the ages of 9 and 12 (Levin, Culhane, Hartmann, Evankovich, \& Mattson, 1991; Welsh, Pennington, \& Groisser, 1991). It is assumed that the basic mechanisms of executive functions working memory, inhibition and flexibility, underlie the ability to plan and 
implement strategies. Their final maturity occurs during the last stage of the executive functions development, from the age of 10 to 14 and later, alongside with the anatomical changes of frontal lobe and its connections with other parts of the brain (Jurado \& Roselli, 2007).

Changes of strategy mechanisms are relatively independent of IQ level during childhood. The longitudinal studies of strategy development indicate an increase in their usage in children with intellectual disability, as well as in children with typical development. However, it was also perceived that children with intellectual disability have difficulties in generating new strategies, as well as in transformation and improvement of existing cognitive strategies (Bray, Fletcher, \&Turner, 1997; Turner, Hale, \& Borkowski, 1996). Persons with intellectual disability (ID) show significant difficulties in verbal fluency tasks, which are associated with lexical processing speed and with problems of executive control (Danielsson, Henry, Rönnberg, \& Nilsson, 2010).

By application of adapted version of Controlled Oral Word Association Test - COWAT) which assesses phonemic fluency, it was determined that children with mild intellectual disability (MID) aged 10 and 14, averagely produce around 11 words on all three given letters jointly, respectively 3-4 words for every letter-stimulus individually (Gligorović \& Buha, 2011). Their results are far behind the phonemic productivity of children with typical development of similar chronological age, who averagely produce a total of 26-30 words on all three given letters together. Performance of the participants with MID is poorer than the performance of seven-year-old children of typical development (Gligorović \& Buha, 2011; Levin et al., 1991; Strauss et al., 2006). The participants with MID averagely produce around 29 words on the Category Naming Test (categories: animals, food and clothing) which assesses semantic fluency. On average, they listed between 9 and 10 words for each of the assessed semantic category, while children of typical population of the same age range name up to 18 words that belong to a certain category (Gligorović \& Buha, 2011). The performance of children with MID on the tasks of this type is more compatible with the semantic productivity of children with typical development at 6 years of age (Gligorović \& Buha, 2011; Levin et al., 1991; Strauss et al., 2006).

Furthermore, our previous study also revealed that children with MID achieve significantly better results on semantic fluency tasks. Productivity 
of persons with typical abilities on phonemic fluency tasks represents half of the semantic productivity, and in participants with MID the phonemic fluency performance is by almost two-thirds poorer with regard to the semantic fluency task performance (Gligorović \& Buha, 2011). Although the difference between semantic and phonemic productivity is present in children (Koren \& Kofman, 2005; Riva, Nichelli, \& Devoti, 2000) and adults (Troyer, 2000) of typical population, the extent of the difference might be an indicator of strategy generation difficulties in children with MID, because the determined difference cannot be explained by vocabulary limitation which is present in most people with ID.

Bearing in mind that phonemic and semantic fluency tasks are frequently used to differentiate executive control roles (phonemic fluency) and the integrity of lexical-semantic representation (semantic, or categorical, fluency) (Luo, Luk, \& Bialystok, 2010), the main goal of this study is to determine the influence of basic components of EFs (flexibility, working memory and inhibitory control) on the phonemic and semantic productivity in children with MID as an indicator of strategy employment. This approach could offer a clearer insight into the nature of the previously determined discrepancy and factors of the phonemic and semantic fluency tasks performance in this group of children.

\section{METHOD}

\section{Participants}

The sample consisted of 95 children with unspecified mild intellectual disability (MID), aged 10-13.11., with no history of genetic, neurological, emotional/behavioural, and sensory disorders. They have been divided into four groups according to their age. The first group consisted of 25 (26.3\%) participants aged 10-10.11, the second 21 (22.1\%) participants aged11-11.11, the third 23 (24.2\%) participants aged 12-12.11 and the fourth group 26 (27.4\%) participants aged 13-13.11. The participants encompassed 43 (45.3\%) girls and 52 (54.7\%) boys. Their IQ ranges from 50 to $70(\mathrm{M}=60.43$, $\mathrm{SD}=7.287)$. All the participants belong to the category of lower $(67.5 \%)$ and medium (32.5\%) socioeconomic status. 
Statistically significant differences of the intellectual level in participants of different age groups $(\mathrm{p}=0.889)$, gender $(\mathrm{p}=0.492)$ and socioeconomic status ( $\mathrm{p}=0.324$ ) have not been found.

Our previous analyses have not determined statistically significant differences in verbal fluency among the participants of different age and gender (Gligorović \& Buha, 2011).

\section{Instruments and Procedure}

Data on age, intellectual abilities and socioeconomic status have been gathered through the analysis of paedagogic-psychological documentation of school services. The research was conducted individually, with parental consent, in three separate sessions. Verbal Fluency Assessment

For the assessment of verbal fluency we used semantic and phonemic fluency tasks. The productivity score (total number of correct words) was used as the basic variable in both tasks.

Phonemic fluency was assessed by means of an adapted version of the Controlled Oral Word Association Test. The most frequent letters in the English language $-F, A$ and $S$ were used in the original version of the test. According to children's vocabulary frequency of Serbian words (Lukić, 1983), the letters $K, M$ and $S$ are the equivalent to those letters, so they were used during the research. The participants are requested to name as many different words (nouns) as possible starting with a given letter, excluding proper names, toponyms, numbers and the same words with different suffixes within $60 \mathrm{~s}$.

Semantic fluency was assessed by the Category Naming Test. The test was an adapted version of semantic fluency task implemented by Welsh et al. (1991). Compared to the original version, we excluded "things to ride" category and extended the answering time. The participants are required to name as many words as possible starting with a given category (food, clothing, animals) in a limited time period (60 s, instead of $40 \mathrm{~s})$. 


\section{Basic Executive Functions Assessment}

Cognitive flexibility, verbal working memory and inhibitory control were assessed within the domain of basic executive functions. The Wisconsin Card Sorting Test - WCST (Heaton, Chelune, Talley, Kay, \& Curtiss, 1993) assesses the ability of generation and shifting of the categorization principle by means of classification task according to one of the three classification criteria (color, form, number of elements) which are changing successively. The test material consists of two decks of cards (64 cards each). The card sorting principle changes after ten consecutive correct matchings, without previous notice of the change. A child is required, based on the examiner's feedback on the matching criterion accuracy, to determine a new one if necessary. The procedure continues until the completion of all six given categories, or until the participant spends all the cards from the deck (a total of 128 attempts/cards). The number of categories completed was used as a variable in this study (maximum 6).

The Trail Making Test - part 2 - TMT (Reitan, 1992) assesses complex conceptual tracking, respectively the flexibility of mental set (shifting). Test material consists of a sheet of paper inscribed with small circles with numbers written within them (from 1 to 13) and Cyrillic letters (from A to $\mathrm{K})$. The participants are required to alternately connect small circles with numbers and letters in the following sequence 1-A-2-B-3-B-4- $\Gamma$, etc. Task completion time and the number of errors are measured. If the participant makes a mistake, an order is given to proceed from the point of error, while the timing is not interrupted. The task-solving time was used as a variable in this study.

Verbal working memory is assessed by means of the Number Manipulation Task (NMT) (Buha \& Gligorović, 2012), which requires memorizing the auditory presented sequential ordered numbers with the increasing number of items, and remembering the number position in the sequence. The participants are expected to hear out the series of numbers, and afterwards to determine which number is positioned before some other number (e.g. in a series of numbers 2, 5, 3 the participant should determine which number is spoken before the number 5 ). Sets of numbers range from 3 to 6 numbers in a sequence. The total number of correct answers, out of a possible 12 , is recorded. 
Inhibitory control is assessed by means of the Day/Night Stroop Task, based on the procedure used by Gerstadt, Hong, and Diamond (1994). This version was selected to avoid the influence of possible reading difficulties on the performance. It consists of 50 items (bright pictures with the sun and dark pictures with the moon and the stars) arranged on two A4 sheets of paper. There are five lines of five items on each A4 paper. The Task has two parts. At the first "reading" a child is required to name what is presented in each picture (e.g. to say "day" when shown the "sun" picture), and to ignore the content of the picture and speak out its opposite (e.g. to say "night" when shown the "sun" picture) in the course of the second "reading". Total time necessary for the task completion in the course of the first and second "reading" is recorded separately, as well as the number of errors during the first and second "reading". Spontaneously corrected errors are not registered. The second task-solving time was used as a variable in this research.

\section{Data analysis}

The analysis of covariance (ANCOVA), analysis of variance (ANOVA), hierarchical multiple regression, Pearson's and partial coefficients of correlation were used in the statistical analysis.

Due to the analysis of covariance implementation, the results of basic executive functions assessment are divided into four groups, each on a percentile ranks basis (a transformation with three cross-sections). The first group contains scores up to $25^{\text {th }}$ percentile ranks, the second from $25-50^{\text {th }}$ percentile, the third up to $75^{\text {th }}$ percentile and the fourth above $75^{\text {th }}$ percentile.

\section{RESULTS}

Although some research results indicate that social factors (socioeconomic status, educational level of parents, etc.) can impact verbal fluency in children (Hurks et al., 2006; Klenberg, Korkman, LahtiNuuttila, 2001), the statistically significant relation between socioeconomic status and phonemic $(\mathrm{F}(1)=0.249, \mathrm{p}=0.619)$ and semantic productivity $(F(1)=0.072, p=0.789)$ has not been determined by our research. The 
statistically significant correlation of IQ and phonemic productivity $(\mathrm{r}=0.427, \mathrm{p}<0.000)$, as well as semantic productivity $(\mathrm{r}=0.329, \mathrm{p}=0.001)$ was determined.

Table 1 -Descriptive statistical parameters of verbal fluency and basic executive components in participants with MID

\begin{tabular}{lrrrr}
\hline & Min & Max & Mean & SD \\
\hline COWAT & 2 & 23 & 11.22 & 5.17 \\
\hline CNT & 14 & 48 & 29.30 & 6.89 \\
\hline WCST & 0 & 6 & 3.98 & 1.57 \\
\hline TMTb & 103.0 & 685.18 & 277.7 & 123.13 \\
\hline NMT & 0 & 10 & 2.49 & 2.35 \\
\hline Day/night2 & 36 & 141 & 65.95 & 21.87 \\
\hline
\end{tabular}

Note: COWAT - Controlled Oral Word Association Test; CNT - Category Naming Test; NMT-Number Manipulation Task.

Due to the possibility of potential influence of IQ on the results, the method of partial correlation (controlled by IQ) was implemented for the purpose of determining the correlation significance between verbal fluency and assessed EFs components. The statistically significant correlation of phonemic productivity and all assessed EFs parameters was determined. The phonemic assessment results (COWAT) correlate to the greatest extent with the TMT $\left(\mathrm{r}^{\text {partial }}=-0.492, \mathrm{p}<0.000\right)$ and WCST $\left(\mathrm{r}^{\text {partial }}=0.391, \mathrm{p}<0.000\right)$, and afterwards with the NMT $\left(\mathrm{r}^{\text {partial }}=0.328, \mathrm{p}=0.003\right)$ and Day/night ${ }_{2}$ Task $\left(\mathrm{r}^{\text {partial }}=-0.322, \mathrm{p}=0.004\right)$.

The semantic fluency results (CNT) significantly correlate with the $\mathrm{TMT}_{\mathrm{b}}\left(\mathrm{r}^{\text {partial }}=-0.267, \mathrm{p}=0.017\right)$ and WCST $\left(\mathrm{r}^{\text {partial }}=0.251, \mathrm{p}=0.025\right)$. Verbal working memory $(\mathrm{NMT})(\mathrm{p}=0.481)$ and inhibitory control $\left(\right.$ Day/night $\left.{ }_{2}\right)$ $(\mathrm{p}=0.073)$ do not significantly correlate with semantic productivity.

The results of EFs assessment are divided into four groups, each based on the percentile ranks (More detailed in Table 2).

Table 2 - Percentile ranks of the executive functions assessment results

\begin{tabular}{lllll}
\hline Percentile Ranks & WCST & NMT & TMTb & Day/night2 \\
\hline$<25$ & $0-2$ & 0 & $337.61>$ & $75.67>$ \\
\hline $26-50$ & 3 & 1 & $235.05-337.60$ & $61.62-75.66$ \\
\hline $51-75$ & 4 & $2-3$ & $192.61-235.04$ & $51.17-61.61$ \\
\hline $75>$ & $5-6$ & $4-10$ & $<192.6$ & $<51.16$ \\
\hline
\end{tabular}


The analysis of covariance (ANCOVA) was implemented for the purpose of verification of the influence of assessed EFs components, independent of IQ, on phonemic and semantic productivity (Detailed in Table 3).

Table 3 - Influence of executive components on phonemic and semantic productivity

\begin{tabular}{ccccccc}
\hline \multirow{2}{*}{ EF } & \multicolumn{3}{c}{ COWAT } & & \multicolumn{3}{c}{ CNT } \\
\cline { 2 - 7 } & $\mathrm{F}(3)$ & $\mathrm{P}$ & ${\text { Partial } \eta^{2}}$ & $\mathrm{~F}(3)$ & $\mathrm{p}$ & Partial $\eta^{2}$ \\
\hline WCST & 8.773 & $\mathbf{0 . 0 0 0}$ & 0.232 & 2.978 & $\mathbf{0 . 0 3 6}$ & 0.095 \\
\hline TMT $_{b}$ & 7.764 & $\mathbf{0 . 0 0 0}$ & 0.219 & 3.550 & $\mathbf{0 . 0 1 8}$ & 0.116 \\
\hline NMT $^{\text {Day/night }}$, & 5.301 & $\mathbf{0 . 0 0 2}$ & 0.155 & 1.128 & 0.343 & 0.038 \\
\hline
\end{tabular}

Note: COWAT - Controlled Oral Word Association Test; CNT - Category Naming Test; NMTNumber Manipulation Task.

Statistically significant values are marked (bold)

The multiple regression analysis is conducted in order to reveal the influence of the examined EFs variables (as a unified model) on phonemic and semantic productivity. Bearing in mind the statistically significant correlation between productivity in both assessed verbal fluency domains and IQ, we selected the hierarchical multiple regression analysis in order to statistically remove IQ influence.

The observed EFs predictor variables jointly explain approximately $40 \%$ of the variability on the phonemic fluency results (Adjusted $\mathrm{R}^{2 \text { change }}=0.389$ ), which is also manifested through significant influence of the EFs model $(\mathrm{F}(4)=13.633, \mathrm{p}<0.000)$.

IQ independently explains approximately $12 \%$ of the variability of the phonemic fluency results (Adjusted $\mathrm{R}^{2}=0.116$ ). Taken together, EFs and intelligence explain about half of the variance (50.5\%) of phonemic productivity.

Although the EFs model significantly influences semantic productivity $(\mathrm{F}(4)=2.822, \mathrm{p}=0.030)$, the assessed $\mathrm{EFs}$ predictor variables jointly explain less than $10 \%$ of the results variability (Adjusted $\mathrm{R}^{2 \text { change }}=0.080$ ). IQ independently explains about $6 \%$ of the variability of the semantic fluency productivity (Adjusted $\mathrm{R}^{2}=0.058$ ). Taken together, the EFs and intelligence explain about $14 \%(13.8 \%)$ of the variance of semantic productivity. 


\section{DISCUSSION}

Persons with intellectual disability generally manifest difficulties in adapting to task requirements, because they often fail to develop effective and systematized cognitive strategies, which represent the method of conscious obtaining paths towards the goal (Gavelek \& Raphael, 1982, as cited in Barton, 1988; Kail, 1993; Merrill \& Taube, 1996). In general, poor phonemic and semantic productivity might be a reflection of phonemic awareness problem, insufficient knowledge of concepts (members of the given categories), poorly organized knowledge or inefficient strategies of words searching and retrieval from mental lexicon. We have analyzed the influence of basic EFs components on verbal fluency, in order to gain insight into the nature of the discrepancy between phonemic and semantic fluency in children with MID.

The results analysis showed that all the assessed EF components significantly affect phonemic productivity. Based on the significance and variability contribution, the ability of generation and flexible mental-set shifting (WCST and $\mathrm{TMT}_{\mathrm{b}}$ performance) is the most significant factor of the Controlled Oral Word Association Test performance.

The mental-set flexibility, or cognitive flexibility, implies the possibility of generation and flexible concept shifting (Smidts, Jacobs, \& Anderson, 2004). Within the domain of phonemic fluency, the role of cognitive flexibility is manifested in the task conceptualization (generation of selection principle) and possibility of shifting from one principle/category to another one. It was determined that verbal working memory and inhibitory control significantly influence the phonemic fluency results as well. Verbal working memory enables active maintenance and manipulation of currently processed information (Baddeley, 1992), while inhibitory control represents a set of mechanisms which enable interference control, ongoing modulation or termination of activity (Brocki \& Bohlin, 2004).

The observed predictor variables jointly explain about $40 \%$ of the variability of phonemic fluency results, which is also manifested in the significance of the EFs model influence $(\mathrm{p}<0.000)$.

Our results indicate that the phonemic fluency is a better indicator of EFs even in the population of children with MID, as well as in children with 
typical development (Sauzeon, Lestage, Raboutet, N’Kaoua, \& Claverie, 2004).

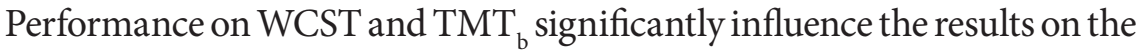
Category Naming Test, but their contribution to the variability is considerably smaller in the semantic fluency domain than in the phonemic one.

Verbal working memory and inhibitory control do not significantly affect semantic productivity. This is an unexpected finding, having in mind their role in the maintenance and shifting of mental representation or strategy.

Although the EFs model has a statistically significant influence on semantic productivity $(\mathrm{p}=0.030)$, the observed predictor variables jointly explain less than $10 \%$ of variability results.

It is possible that semantic fluency difficulties are primarily influenced by insufficient lexical repertoire (scant number of words for required semantic categories) or poorly organized knowledge. Presumably, semantic fluency in children with MID, as well as in children with typical development (Sauzeon et al., 2004), is initially connected with the categorical knowledge development, particularly with the ability of taxonomy based conceptualization.

\section{CONCLUSION}

The analysis of the EFs influence on semantic and phonemic productivity is conducted based on our previous study results. In aforementioned study, the phonemic fluency productivity in participants with MID is by almost two-thirds lower than the semantic fluency task performance (Gligorović \& Buha, 2011).

According to the results of our present study, it is noted that all the assessed EFs components significantly affect phonemic productivity, explaining approximately $40 \%$ of results variability. Semantic productivity is significantly influenced by cognitive flexibility, but not verbal working memory and inhibitory control. The observed EFs predictor variables jointly explain less than $10 \%$ of the variability of semantic fluency results. 
The results of our study indicate that the discrepancy between phonemic and semantic productivity is primarily an expression of difficulties in the domain of strategic searching and retrieval in children with MID, which is directly associated with the basic EFs components - cognitive flexibility, working memory, and inhibitory control.

While discussing the causes of the determined insufficient efficacy of basic EFs in creating and/or applying the appropriate non-routine strategies, one should bear in mind that the development of EFs skills is influenced by both, biological maturation and environmental experiences (Welsh, Friedman, \& Spieker, 2006). Apart from the possible biological maturation factors, a number of environmental factors can also influence the EFs development in children with ID.

Learned helplessness is one possible negative effect of environment that is characterized by high degree of external control (Peterson, Maier, \& Seligman, 1993), and usually care providers and parents are prone to overprotect people with disabilities (Sanders, 2006). According to Maier, Peterson, and Schwartz (2000), experience of not being able to control most of the important events results in slower problem solving, failure in mastering tasks, and perseveration with unhelpful strategies. Our research showed that children with MID use routine strategies more successfully, while the ability to generate new, non-routine strategies is limited due to the limitation of basic EFs.

Bearing in mind that artificial conditions in short-term interventions in strategy development usually do not result in maintenance of treatment gains over time or transfer to real-world activities (Baker, Gersten, \& Scanlon, 2002), metacognitive strategies also must be incorporated in education curricula and in the context of meaningful everyday tasks. Strategy repertoire (both verbal and nonverbal), its selection and their use is essential to higher level of behavioural organization, which is a basis for learning and adaptive functioning (Borkowski \& Muthukrishna, 1992; Gligorović \& Buha, 2013; Gourgey, 2001; Hartman, 2001), and thus teaching academic content without teaching strategies tends to result in students failing to implement their acquired knowledge out of the learning context. Students must learn how to choose adequate cognitive strategy, which includes the idea when to use certain strategies, why some procedure works and in which conditions, or why some procedure is better 
than the other in some particular situation (the reasons behind particular procedure). Apart from addressing cognitive strategies itself, treatment and curricula needs to target all aspects of EFs in a unified manner. However, in order to increase the use of metacognition-related teaching, it is necessary to increase teachers' understanding of information-processing as a foundation of effective learning. Finally, considering that everyday routines are the ideal locus for effective EFs intervention, it is necessary to help parents to reduce overprotective behaviour and to become effective providers of contextualized rehabilitation in their home environment.

\section{REFERENCES}

1. Barton, J. A. (1988). Problem-solving strategies in learning disabled and normal boys: Developmental and instructional effects. Journal of Educational Psychology, 80, 184-191. doi: 10.1037/0022-0663.80.2.18

2. Baddeley, A. (1992). Working memory. Science, 255, 556-559. doi: 10.1126/science.1736359

3. Baker, S., Gersten, R., \& Scanlon, D. (2002). Procedural facilitators and cognitive strategies: Tools for unraveling the mysteries of comprehension and the writing process, and for providing meaningful access to the general curriculum. Learning Disabilities Research and Practice, 17, 65-77. doi: 10.1111/1540-5826.00032

4. Borkowski, J. G., \& Muthukrishna, N. (1992). Moving metacognition into the classroom: Working models and effective strategy teaching. In M. Pressley, K. R. Harris, \& J. T. Guthrie (Eds.), Promoting Academic Competency and Literacy in Schools (pp. 477-501). New York, NY: Academic Press.

5. Bray, N. W., Fletcher, K. L., \& Turner, L. A. (1997). Cognitive competencies and strategy use in individuals with mental retardation. In W.E. Jr. MacLean (Ed.), Ellis' Handbook of Mental Deficiency: Psychological Theory and Research $3^{\text {rd }}$ ed. (pp. 197-217). Mahwah, NJ: Lawrence Erlbaum Associates.

6. Brocki, K. C., \& Bohlin, G. (2004). Executive functions in children aged 6 to 13: a dimensional and developmental study. Developmental Neuropsychology, 26, 571-593. doi: 10.1207/s15326942dn2602_3 
7. Buha, N., \& Gligorović, M. (2012). Relationship between working memory and intellectual functioning in children with mild intellectual disability (in Serbian). Specijalna edukacija i rehabilitacija, 11, 21-38. doi:10.5937/specedreh1201021B

8. Danielsson, H., Henry, L., Rönnberg, J., \& Nilsson, L. G. (2010). Executive functions in individuals with intellectual disability. Research in Developmental Disabilities, 31, 1299-1304. doi: 10.1016/j. ridd.2010.07.012

9. Espy, K. A., Kaufman, P. M., Glisky, M. L., \& McDiarmid, M. D. (2001). New procedures to assess executive functions in preschool children. The Clinical Neuropsychologist, 15, 46-58. doi: 10.1076/clin.15.1.46.1908

10. Filipetti, V. A., \& Allegri, R. (2011). Verbal fluency in spanishspeaking children: Analysis model according to task type, clustering, and switching strategies and performance over time. The Clinical Neuropsychologist, 25, 413-436. doi: 10.1080/13854046.2011.559481

11. Gerstadt, C. L., Hong, Y. J., \& Diamond, A. (1994). The relationship between cognition and action: Performance of 3.5 to 7-year-olds on stroop-like day-night test. Cognition, 53, 129-153. doi: 10.1016/00100277(94)90068-x

12. Gligorović, M., \& Buha, N. (2011). Verbal fluency in children with mild intellectual disability (in Serbian). Specijalna edukacija i rehabilitacija, 10, 595-612.

13. Gligorović, M., \& Buha, N. (2013). Problem solving verbal strategies in children with mild intellectual disability (in Serbian). Specijalna edukacija i rehabilitacija, 12, 11-23. doi:10.5937/specedreh12-3333

14. Gourgey, A. F. (2001). Metacognition in basic skills instruction. In H. J. Hartman (Ed.), Metacognition in Learning and Instruction (pp.17-32). Dordrecht, Nederland: Kluwer Academic.

15. Hartman, H. J. (2001). Developing students' metacognitive knowledge and skills. In H. J. Hartman (Ed.), Metacognition in Learning and Instruction (pp. 33-68). Dordrecht, Nederland: Kluwer Academic.

16. Heaton, R. K., Chelune, G. J., Talley, J. L., Kay, G. G., \& Curtiss, G. (1993). Wisconsin Card Sorting Test Manual. Odessa, FL: Psychological Assessment Resources. 
17. Hurks, P. P. M., Vles, J. S. H., Hendriksen, J. G. M., Kalff, A. C., Feron, F. J. M., Kroes, M.,...Jolles, J. (2006). Semantic category fluency versus initial letter fluency over 60s as a measure of automatic and controlled processing in healthy school-aged children. Journal of Clinical and Experimental Neuropsychology, 28, 684-695. doi: 10.1080/13803390590954191

18. Jurado, M. B., \& Roselli, M. (2007). The elusive nature of executive functions: a review of our current understanding. Neuropsychology Review, 17, 213-233. doi: 10.1007/s11065-007-9040-Z

19. Kail, R. (1993). The role of global mechanisms in developmental change in speed of processing. In M. L. Howe, \& R. Pasnak (Eds.), Emerging Themes in Cognitive Development (Vol. 1) (pp. 97-116). New York, NY: Springer-Verlag.

20. Klenberg, L., Korkman, M., \& Lahti-Nuuttila, P. (2001). Differential development of attention and executive functions in 3- to 12-year-old Finnish children. Developmental Neuropsychology, 20, 407-428. doi: 10.1207/S15326942DN2001_6

21. Koren, R., \& Kofman, O. (2005). Analysis of word clustering in verbal fluency of school-aged children. Archives of Clinical Neuropsychology, 20, 1087-1104. doi: 10.1016/j.acn.2005.06.012

22. Levelt, W. J. M. (1999). Models of word production. Trends in Cognitive Sciences, 3, 223-232. doi: 10.1016/s1364-6613(99)01319-4

23. Levin, H. S., Culhane, K. A., Hartmann, J., Evankovich, K., \& Mattson, A. J. (1991). Developmental changes in performance on tests of purported frontal lobe functioning. Developmental Neuropsychology, 7, 377-395. doi: 10.1080/87565649109540499

24. Lukić, V. (1983). Children's Lexical Frequency Dictionary (in Serbian). Beograd, SFRJ: Prosveta.

25. Luo, L., Luk, G., \& Bialystok, E. (2010). Effect of language proficiency and executive control on verbal fluency performance in bilinguals. Cognition, 114, 29-41. doi: 10.1016/j.cognition.2009.08.014

26. Maier, S. F., Peterson, C., \& Schwartz, B. (2000). From helplessness to hope: the seminal career of Martin Seligman. In J. E. Gillham (Ed.), The Science of Optimism and Hope (pp. 11-37). Radnor, PA: Templeton foundation press. 
27. Merrill, E. C., \& Taube, M. (1996). Negative priming and mental retardation: the processing of distractor information. American Journal on Mental Retardation, 101, 63-71.

28. Peterson, C., Maier, S.F., \& Seligman, M. E. P. (1993). Learned Helplessness: A Theory for the Age of Control. New York, NY: Oxford University Press.

29. Reitan, R. M. (1992). Trail Making Test: Manual for Administration and Scoring. South Tucson, AZ: Reitan Neuropsychology Laboratory.

30. Riva, D., Nichelli, F., \& Devoti, M. (2000). Developmental aspects of verbal fluency and confrontation naming in children. Brain and Language, 71, 267-284. doi: 10.1006/brln.1999.2166

31. Sanders, K. Y. (2006). Overprotection and lowered expectations of persons with disabilities: The unforeseen consequences. Work: A Journal of Prevention, Assessment and Rehabilitation, 27, 181-188.

32. Sauzeon, H., Lestage, P., Raboutet, C., N'Kaoua, B., \& Claverie, B. (2004). Verbal fluency output in children aged 7-16 as a function of the production criterion: Qualitative analysis of clustering, switching processes, and semantic network exploitation. Brain and Language, 89, 192-202. doi: 10.1016/S0093-934X(03)00367-5

33. Smidts, D. P., Jacobs, R., \& Anderson, V. (2004). The Object Classification Task for Children (OCTC): A measure of concept generation and mental flexibility in early childhood. Developmental Neuropsychology, 26, 385-401. doi: 10.1207/s15326942dn2601_2

34. Strauss, E., Sherman, E. M. S., \& Spreen, O. (2006). A Compendium of Neuropsychological Tests: Administration, Norms and Commentary (3rd. ed.). New York, NY: Oxford University Press.

35. Troyer, A. K. (2000). Normative data for clustering and switching on verbal fluency tasks. Journal of Clinical and Experimental Neuropsychology, 22, 370-378. doi: 10.1076/1380-3395(200006)22:3;1-V;FT370

36. Turner, L. A., Hale, C. A., \& Borkowski, J. G. (1996). Influence of intelligence on memory development. American Journal on Mental Retardation, 100, 468-480.

37. Welsh, M. C. (2001). The prefrontal cortex and the development of executive functions. In A. Kalverboer \& A. Gramsbergen (Eds), Handbook of Brain and Behavior Development (pp. 767-789).Dordrecht: Kluwer. 
38. Welsh, M. C., Friedman, S. L., \& Spieker, S. J. (2006). Executive functions in developing children: current conceptualizations and questions for the future. In K. McCartney \& D. Phillips (Eds), Blackwell Handbook of Early Childhood Development (pp. 167-187). Oxford: Blackwell Publishing.

39. Welsh, M. C., Pennington, B. F., \& Groisser, D. B. (1991). A normativedevelopmental study of executive function: A window on prefrontal function in children. Developmental Neuropsychology, 7, 131-149. doi: $10.1080 / 87565649109540483$ 


\title{
VERBALNA FLUENTNOST KOD INTELEKTUALNO OMETENE DECE: UTICAJ OSNOVNIH EGZEKUTIVNIH KOMPONENETI
}

\author{
Milica Gligorović, Nataša Buha \\ Univerzitet u Beogradu - Fakultet za specijalnu edukaciju i rehabilitaciju
}

\begin{abstract}
Summary
Zadaci fonološke i semantčke fluentnosti se često koriste u svrhu diferenciranja uloga egzekutivne kontrole i integriteta leksičko-semantičke reprezentacije. Glavni cilj ovog istraživanja je utvrđivanje uticaja osnovnih egzektivnih komponeneti na fonološku i semantičku produktivnost dece sa lakom intelektualnom ometnošću.

Uzorak čini 95-oro dece sa nespecifikovanom lakom intelektualnom ometenošću (LIO), uzrasta od 10 do 13.11 godina. Za procenu fonološke fluentnosti korišćen je Test kontrolisanih usmenih asocijacija, dok je semantička fluentnost procenjena Testom kategorijalnog imenovanja. Kognitivna fleksibilnost je procenjena Viskonsin testom sortiranja karata i Testom trasiranja puta. Za procenu verbalne radne memorije korišćen je Zadatak manipulacije brojevima u nizu, dok je Dan-noć verzija Strup zadatka korišćena za procenu inhibitorne kontrole.

Analiza rezultata je pokazala da sve procenjene komponenete egzekutivnih funkcija značajno utiču na fonološku produktivnost. Semantička produktivnost $\mathrm{u}$ mnogome zavisi od postignutih rezultata na Viskonsin testu sortiranja karata i Testu trasiranja puta. Verbalna radna memorija i inhibitorna kontrola ne utiču značajno na semantičku produktivnost.

Rezultati našeg istraživanja ukazuju na to da diskrepanca između fonološke i semantičke produktivnosti kod dece sa LIO može biti direktno povezana sa komponentama osnovnih egzekutivnih funkcija.

Ključne reči: verbalna fluentnost, egzekutivne funkcije, laka intelektulana ometenost
\end{abstract}

Primljeno: 29.9.2014.

Prihvaćeno: 22.10 .2014 . 